\title{
Humour in colloquial conversation ${ }^{1}$
}

\author{
María Belén Alvarado Ortega \\ University of Alicante, Spain \\ Belen.Alvarado@ua.es
}

\begin{abstract}
Researchers from the GRIALE group (Irony and Humour Research Group) have developed a theoretical method that can be applied to humorous ironic utterances in different textual genres, depending on the degree of the violation of conversational principles in conversation. In addition to this, the General Theory of Verbal Humor (Attardo and Raskin, 1991) will be taken into account in the analysis. Therefore, I will study irony and humour in conversational utterances in real examples of Peninsular Spanish obtained from the COVJA, (Corpus de conversaciones coloquiales [Corpus of Colloquial Conversations]) and CREA, (Corpus de Referencia del Español Actual [Reference Corpus of Present-Day Spanish]). The focus of this paper is then the application of the aforementioned theories to humorous ironic statements which arise in conversation. I will also examine the positive or negative effects caused by them, which will additionally verify if irony and humour coexist in the same conversational exchange, and if this has a communicative goal.
\end{abstract}

Keywords: irony, humour, politeness, effect.

\section{Introduction}

This paper proposes the analysis of ironic utterances with a humorous effect in conversation. Humour has so far been preferentially studied in humorous genres, where the listener is predisposed to humour, such as monologues (Ruiz Gurillo 2012), jokes (Yus 1996), comic strips (Ruiz Gurillo \& Padilla 2009) or humorous texts (Attardo 2001a). For this reason, the present paper aims at analyzing colloquial utterances in conversation, where humour appears in the utterance without the listener expecting $\mathrm{it}^{2}$. I will demonstrate that in many of these cases humour becomes a narrative and social strategy, similarly to irony and politeness. My starting hypothesis in this paper is that irony with humour -along with other effects such as politeness-is 
used in conversation for a positive purpose such as strengthening ties between speaker and listener, thus denying the idea that irony and humour can only coexist with negative effects in conversation.

Therefore, although there are studies related to humour which develop the idea that humour is a form of aggression -like Gruner (1978, 2000) or Garmendia (2010), amongst others- some of the researchers promote the idea that humour in ironic utterances can be a way of enhancing group cohesion (Norrick, 2003: 1342; Alba Juez 2000, 2001), which will be another of my main goals, too. First and foremost, I will try to argue that positive humour exists as a conversational strategy ${ }^{3}$. In my opinion, irony is a pragmatic phenomenon and humour is a consequence of the presence of irony in conversation (Ruiz Gurillo 2012).

For my purposes, I will start from the analysis of the study of irony and humour in Spanish (Ruiz Gurillo and Padilla, 2009) and the relationship of irony, humour and politeness, as developed by the GRIALE group, and from the study carried out within the framework of the General Theory of Verbal Humor ${ }^{4}$ (hereinafter GTVH). This theory has been put forward by Attardo (2001a, 2008) and Attardo and Raskin (1991) for the analysis of humorous utterances. In our view, the latter proposal is partly in tune with the GRIALE group's theoretical approach (Ruiz Gurillo and Padilla, 2009) because the latter presents a study of irony and humour from a pragmatic and conversational standpoint and can additionally be applied to all sorts of utterances, and not only to those appearing in humorous genres (see section 2). This study will be corroborated with 200 examples of humour extracted from the Corpus de conversaciones coloquiales [Corpus of Colloquial Conversations] and the Covja (Corpus de la variedad juvenil universitaria del español hablado en Alicante) [Corpus of the young university variety of the Spanish spoken in Alicante], seeking to verify whether or not the model suggested by both the GRIALE group and Attardo's model provide a new perspective for the analysis of these conversational utterances where humour and other phenomena appear as communicative strategies (section 3 below); and finally, a number of conclusions will be drawn in relation to the study of humour and irony (section 4).

\section{Humour and irony in the context of interaction}

Most of the studies that discussed the link existing between irony and humour have focused on analyzing the concept of aggression ${ }^{5}$. This is why they have resulted in preconceived ideas about irony and humour as forms used in interaction for the purpose of showing the speaker's superiority over the listener (Gruner 2000, Garmendia 2010, amongst others).

Nevertheless, it has been observed that in ironic-humorous conversational utterances irony and humour are pragmatic events which can coexist in interaction without the interlocutor necessarily being attacked (Alvarado 2012). In these cases, irony and humour are used to obtain mutual understanding between the interlocutors (Clift 1999, Alba Juez 2000, Gibbs 2000, Kotthoff 2002, Norrick 2003, Priego Valverde 2006), and even to show politeness; these are positive aims in conversation and are regarded as conversational strategies. 


\subsection{Verbal irony}

The most important explanations of the nature of verbal irony refer to various theories which state that irony is an indirect speech act (Searle 1980), a transgression of the Maxim of Quality (Grice 1991[1975]), a category which entails an interpretative use of language, which is explained as an echo (Sperber and Wilson, 1994: 274; Wilson and Sperber, 2004: 265), or even as an argumentative resource or polyphony (Anscombre and Ducrot 1994).

I will focus on the GRIALE group's approach in order to explain irony ${ }^{6}$, for two reasons: it offers a systematic explanation of verbal irony and it is compatible with the theory of S. C. Levinson (cf. Rodríguez Rosique 2009). Without denying the particularized nature of irony, it is considered essential to resort to those generalizable inferences which imply some indicators and marks as ironic ${ }^{7}$. GRIALE defines marks as those cues which are helpful in the ironic interpretation (intonation, gestures...), whereas indicators are ironic structures as such (e.g. idioms). The ironist uses indicators and leaves marks that will serve as a guide to the listener to interpret the speaker's words. Irony is thus explained by the GRIALE Group through the inversion $^{8}$ of the Levinson conversational principles (Rodríguez Rosique, 2009: 120). It is worth remembering that Levinson' (2000) starts from the fact that the Quality requirement (of a true utterance) is a pre-condition of every communicative exchange. When this is not met, it is because some participant in the communicative act has violated one of Levinson's conversational principles (2000).

For GRIALE, the inversion of different principles in ironic contexts gives rise to different types of irony (prototypical, which means a denial of what is said, or unprototypical, which implies another linguistic mechanism $)^{10}$. Thus, when the Principle of Quantity (Q) -the one assuming that we should provide precise information- is violated in an ironic utterance, prototypical irony (saying the opposite) is achieved, as inferences are obtained by denying what is said. For instance:

(1)

A: Excuse me, what do you think of Monica Lewinsky?

B: Monica Lewinsky? Well, as far as I know she is a very loyal person.

The utterance can be interpreted literally, i.e. that Monica Lewinsky is loyal and devoted to her friends, or non-literally because Monica Lewinsky actually became famous for denouncing President Clinton after having a sexual relationship with him. For this reason, the word "loyal" should be interpreted in its opposite sense (prototypical irony).

In contrast, irony is not prototypical in those cases where we invert the Principle of Informativity (I) -which suggests giving sufficient information- and the Principle of Manner (M) -which recommends not to use ambiguous expressions: irony is implied by multiplicity of referents in the first case or by marked expressions in the second (Ruiz Gurillo 2010). Ruiz Gurillo (2010: 110) similarly proposes to treat as prototypical those examples of irony in which Levinson's (2000) Principle of Quantity is inverted and as non-prototypical those in which the Principle of Informativity or Manner are inverted. In the examples below in (2), the speaker inverts Principles of Informativity and Manner, whereas in (3) only the Principle of Manner is inverted: 
A: Rafa Nadal is called the king of clay, but he is angry because he thinks that he is the king of the earth.

(3)

A: Do you have any health problem?

B: I have extrasystolic arrhythmia and I had a heart attack two years ago. But nothing important, I am ready to donate blood.

In (2) the speaker inverts Principles of Informativity and Manner to be ironic because he uses king of clay as a tennis idiom in Spanish and the listener is led to understand it literally. In (3) B answers with an expression marked by technical words to be ironic too, so the Principle of Manner is inverted.

Consequently in the utterances ironic expressions are used to refer literally, but they are not prototypical instances of irony, because these expressions do not deny the initial statement explicitly. In other words, the theory put forward by GRIALE finds its main driving force in inversion, that is, the particularized conversational implicatures generated by the utterance would be inverted by some maxims and, therefore, the conversational principles are in turn inverted (prototypical irony, though scalar). This fact prevails over other conversational principles which might be considered unconsciously by the speaker in the same utterance, such as the Manner or Quantity Principles. This explanation allows us to find certain recurrent patterns in the interpretation of irony in utterances -despite the belief that irony is essentially contextual. Furthermore, the marks and indicators appearing in the utterance help to create an ironic context that the listener must understand as ironic (see Ruiz Gurillo and Padilla 2009).

Irony is consequently conceived of as a pragmatic phenomenon based on indicators and marks, which is why it is possible to offer an explanation that goes beyond the particular contexts where irony arises. Therefore, GRIALE's model allows me to explain a greater number of humorous ironic examples with an inferred meaning than other models.

\subsection{Verbal humour}

Humour has been treated from different points of view, e.g. sociolinguistic, ethnographic, etc., although my focus of interest in this paper is the pragmatic view.

Attardo (1994: 47) highlights some perspectives from which humour has been considered: the aggression theories (for which every humorous experience arises as an expression of superiority felt by a human being towards another human being), the release theories (for which humour is a final effect resulting from a release of accumulated energy) and the incongruity theories (according to which humour is based on the discovery of a meaning or a thought that turns out to be inconsistent with what was expected) (cf. footnote 5). Of all these approaches, it is the incongruity theories that I am interested in because they broadly adopt a pragmatic approach, even though we can also find different perspectives among them, such as relevance theory and the GTVH. Furthermore, these theories can be applied to specific contextual utterances and they cannot establish generalizations about the use of irony and humour in conversations.

Thus, Yus (1996: 502) states from a relevance-theoretic perspective that humour is a strategy that he calls incongruity-resolution (cf. Suls 1972). In this strategy, the speaker produces invalid cognitive expectations and the listener has to resolve the cognitive dilemma. The listener 
recognizes that he has been deceived since he has not taken other possible interpretations into account. This deception recognition on the part of the listener gives rise to the humorous effect. The breaking of expectations is claimed to take place in terms of relevance (Yus, 1996: 504), that is, the listener interprets the utterance according to the degree of pertinence that it has and rules out the information which is not relevant to interpret the utterance correctly. This exclusively relevance-theoretic approach does not help me to generalize on conversational exchanges because it depends on the context of each utterance; hence my decision to analyze Attardo's proposal for a General Theory of Verbal Humor (2001a).

Two phenomena exist in humour according to Attardo (2001b: 167), namely: humour competence and humour performance. The former is the ability that allows the speaker and the listener to generate and recognize humour within a specific context, whereas the latter one has to do with the desire as well as the willingness to accept it. Therefore, both the speaker and the listener take part in the interaction with marks in the utterance that help the interlocutor to interpret that utterance properly (Alvarado 2006). This is the idea which connects Attardo's GTVH with GRIALE's proposal, according to which every communicative exchange places at the listener's disposal indicators or marks -i.e. linguistic mechanisms using Attardo's terminology- which serve as clues to interpret the utterance in an ironic and humorous way. For this reason, I will adjust Attardo and Raskin's GTVH (1991) in order to apply it later to the utterances analyzed in this paper.

In accordance with the GTVH (Attardo, 2001a: 22; 2008: 108) six types of knowledge resources exist which make it possible to detect whether a text is humorous or not and exhibit a hierarchical relationship. These knowledge resources are: script opposition, logical mechanism, situation, target, narrative strategy, and, finally, language. This theory permits to analyze more complex forms of humour than jokes, for instance, humour in interaction or in monologues.

Attardo (2001a: 62) points out that humour is different depending on whether it takes place in narrative texts or in conversation. The essential difference lies in the planning (or the lack of it), and the importance that the context has for a correct utterance interpretation. However, the method applied to the analysis of the different humour texts is the same (Attardo, 2001a: 82), as it has to do with the identification of the humorous lines whether they are situated in the plot (jab lines) or at the end of the text (punch lines). They are identical elements semantically speaking, and the only differences they display are their textual position and their pragmatic function. Therefore, if they appear in the middle of the conversation, they help to provide the listener with clues about their humorous intention, i.e. they are used as a jab line, whereas they represent a humorous punch line when they appear at the end.

In those cases where a punch line appears, the speaker forces the listener to activate a new semantic framework or script to ensure a correct utterance interpretation, which contrasts with the one appearing at the beginning of the text. All this is perfectly complementary to the explanation suggested by GRIALE for ironic-humorous utterances, since the listener can interpret the communicative exchange as ironic and humorous through indicators and marks (the language knowledge resource described by Attardo) (Alvarado 2006). Moreover, because conversational exchanges, on which this paper focuses, are not a humorous genre, such as the humorous monologue or the joke, the listener has to use his/her pragmatic ability to understand the humour (humour performance).

From the interactional point of view, Hay (2000) and Holmes and Marra (2002) carry out a study of humour as a social strategy that helps to strengthen interpersonal relationships. Hay 
(2000) argues that solidarity is a function of humour in conversation, an idea that I share when it comes to explaining its effects on conversation.

Irony and humour are both interpretative language forms and they also involve the essentially pragmatic contrast and indirect negation. In their condition as pragmatic facts, they both violate pragmatic principles (Ruiz-Gurillo 2012, Rodríguez-Rosique 2009). In fact "irony may contribute to the perception of humour in a text" (Attardo, 2001a: 122). Although contact points exist (humorous irony and ironic humour), irony and humour are actually distinct phenomena: unlike irony, which is essentially a pragmatic fact, humour is simultaneously semantic and pragmatic. Furthermore, irony echoes explicitly communicated assumptions while humour echoes implicitly expressed ones. Irony additionally entails negative inferences, whereas humour requires a substitution of one script for another. More specifically, irony is understood as indirect negation, while humour basically revolves around a script-replacing antonymic mechanism. With regard to the inferences involved, irony primarily entails the violation of the Principle of Quantity and Manner. Instead, humour involves the infringement of the Informativity and Manner Principle (Ruiz-Gurillo, 2012: 131-141). To summarize all these ideas, I consider that irony and humour can coexist in a conversational utterance, because irony is a resource of humour, and humour is an effect of irony, as we will see in the examples below.

\section{The effects of irony and humour on conversation}

The previous section aimed at explaining what is understood by 'irony' and 'verbal humour' as proposed by GRIALE (Ruiz Gurillo and Padilla 2009) for irony in Spanish and by the General Theory of Verbal Humor (Attardo 2001a).

Concerning humour performance, Attardo (2001a: 120) relates irony and humour in interaction and points out that both are basically used as social management strategies. Among other reasons for which irony is used, Attardo highlights the -inclusive as well as exclusivegroup membership; sophistication, which has to do with the speaker's mental skill; evaluation, understood as an attitude towards the utterance or its assessment; and politeness, which serves to protect the speaker's social image in communicative exchanges ${ }^{11}$.

As we can see, the effects that humour can exert on conversation quite often have to do with those likely to be produced by irony, and they can affect face work and politeness ${ }^{12}$. After all, humour and irony are two pragmatic events that have been inherited from traditional rhetoric, as is explained by Hidalgo and Iglesias (2009: 424). Furthermore, humour has been treated as a phenomenon which evaluates irony, i.e. the speaker uses an ironic utterance to laugh down his listener, consequently damaging his public face.

We can observe that irony and humour are in turn positively related to politeness ${ }^{13}$, that is, their use helps both to highlight the interlocutor's positive face and to strengthen ties (Alvarado 2012). As for politeness, Brown and Levinson (1978, 1987: 13) state that it is based on the concept of face as public face, which needs to be protected and, to that end, an effort must be made to avoid damaging other people's public image:

Central to our model is a highly abstract notion of face which consists of two specific kinds of desire (face-wants) attributed by interactants to one another: the desire to be unimpeded in one's actions (negative face), and the desire (in some respects) to be approved of (positive face).

(Brown and Levinson 1978, 1987: 13) 
The positive image is the one that the individual has about himself, for which he aspires to obtain recognition by the other group members; in other words, the individual would like others to accept his personality and behaviour in some of their manifestations. In contrast, the negative image refers to each individual's hope that his acts will not be treated disrespectfully by the others, i.e. that his actions will not be impeded and that his right to privacy will be reinforced. In this way, the speaker can develop communication strategies that help him/her both to maintain his/her positive face and to defend his/her negative face against the listener's verbal attack.

In their work, Brown and Levinson $(1978,1987$ : 213) list a series of indirect linguistic strategies -among them jokes and irony- that produce politeness. According to these authors, these strategies do help the speaker to defend his/her public face by means of conversational implicatures; in other words, the speaker does not clearly express his/her intervention because it would violate the Maxims of Manner and Informativity (Rodríguez Rosique, 2009: 110), and the listener has to infer in ironic-humorous terms what the speaker is trying to communicate with his/her utterance. All this allows us to deduce that irony and humour are strategies which can use politeness to reach their ultimate aim, as will be confirmed by the analysis of examples.

Therefore, it seems that I can apply to humour the scheme (see Figure 1) used to summarize the effects of irony on conversation along with its connection to politeness and put forward in a previous paper (Alvarado, 2009: 337). Furthermore, I will demonstrate -thanks to the application of the GTVH and to the study carried out by the GRIALE group - that both phenomena function similarly in conversation:

\begin{tabular}{|c|c|c|}
\hline $\begin{array}{c}\text { HUMOUR WITH A } \\
\text { NEGATIVE EFFECT }\end{array}$ & HUMOL & $\begin{array}{l}\text { H A POSITIVE EFFECT } \\
\text { (- politeness) }\end{array}$ \\
\hline -At the listener & \multirow{3}{*}{$\begin{array}{l}\text { Humour with a } \\
\text { positive image }\end{array}$} & -At the listener \\
\hline -At an absent person & & -At an absent person \\
\hline \multirow[t]{2}{*}{-At a situation } & & -At a situation \\
\hline & $\begin{array}{l}\text { Humour with a } \\
\text { negative image }\end{array}$ & $\begin{array}{c}\text {-Self-humour (the speaker makes } \\
\text { humour about himself) }\end{array}$ \\
\hline
\end{tabular}

Figure 1. Humour and its effects (Alvarado, 2009: 337)

I can consequently distinguish two kinds of humour depending on their effects on the conversation. Humour with a negative effect arises in an utterance when we find damage to the public face of the listener or of an absent person or we criticize a situation. In these cases, politeness is not present because the context does not admit it due to the appearance of an image attack, so impoliteness may appear, when the listener's face is damaged by the speaker, as a way to protect his/her public face.

If there is no damage and criticism in the humorous utterance, the utterance has humour with a positive effect, and pragmatic strategies appear to strengthen ties between speaker and hearer. Furthermore, this latter type of humour with a positive effect may in turn convey a negative 
image or a positive image, and politeness ${ }^{14}$ is likely to appear as a pragmatic strategy. If humour conveys a negative image, the result will be self-humour, which means that the speaker produces humour about himself in order to keep his social image and make sure that the rest of the participants in the conversation recognize his identity and behaviour. Finally, if it is humour with a positive image, the speaker wants to be integrated into the conversational group and humour can be addressed at the listener, at an absent person or at a situation ${ }^{15}$.

We will see all the differences between positive and negative effects in the analysis of the examples below, and we will see that humour and irony are two communicative strategies at the service of the speaker. They can additionally be used to include or exclude someone from the conversational group; humour and irony coexist in the conversational utterance, as will be also shown in the study of the occurrences presented below.

In (4) ${ }^{16}$ we can observe several interlocutors talking about the time spent abroad by A as a student and about the food he prepared for himself:

(4)

C: perooo un plato combinao

A: ¡coño! platos combinaos me lo hago $\square$ yoई

B: $\quad$ \& de tapas ni de coña $\square$ ¿no $\square \oint$

A: $\quad$ S tenía una- tapas tampoco $\square$ iqué

va!// plato combinao me lo hago yo/ si tenía alli yooo una cocina/// mis huevos y mis cosas

(RISAS)

$C:[(R I S A S)]$

$B:[(R I S A S)=]$

D: [sus huevos $]^{17}$

$B:=$ sus huevos y sus- $\S$

D: $\quad$ $\quad$ mis huevos y yo somos asii ${ }^{18} \S$

(Briz and grupo Val.Es.Co., 2002:62 [H.38.A.1:469-480])

C: buuut a meal on one plate [e.g. with burgers, eggs and fries]

A: for goodness sake! I can prepare my own meals on one plate

B: $\quad$ of tapas [small portions of food] no way, right?

A: $\quad$ I had one-not tapas either-of course

not//I can prepare myself a meal on one plate//I...I... actually had a kitchen there///my eggs

and my things (LAUGHTER)

$C:$ [LAUGHTER]

$B:[($ LAUGHTER $)=]$

D: [his eggs]

$B:=$ his eggs and his

D: $\quad$ my eggs and I are like that

We can observe in (4) how humour is triggered by the utterance mis huevos y mis cosas [my eggs and my things] -reproduced by A- in which there is a play on words based on the polysemy of the word huevos [eggs, as a dish or as testicles because of their oval shape], as an irony indicator (GRIALE approach). Thus, listeners D and B interpret the utterance ironically and $\mathrm{D}$ builds a sentence mis huevos y yo somos asi [my eggs and I are like that] in direct speech -emulating A's words- where the use of huevos is interpreted with a sexual meaning as testicles. That is how laughter is triggered ${ }^{19}$ as a direct consequence of verbal humour in this particular case.

This example additionally illustrates a violation of the Informativity and Manner Principles, since the use by the speaker of polysemous words which act as indicators of irony 
activates several referents which the listener interprets suitably; in other words, a script opposition has taken place based on the ambiguity of meaning in the word huevos -as food or as a male sexual organ. It must be added that the logical interpretation mechanism has been altered by an imperfect reasoning, since the listener has interpreted 'eggs' as 'testicles', when he is really talking about food. The utterance's situation is produced in a colloquial conversation between some friends who have decided to go to the countryside and have lunch there and they are talking about food. In his utterance, the speaker does not seek to create humour from the start; however, the relaxed situation he finds himself in together with the ambiguity of the word he uses leads the listeners to make a humorous interpretation of mis huevos y mis cosas, which acts as a jab line. That is why his interlocutors continue and reproduce the humorous punch line mis huevos y yo somos asi in direct speech. Due to all this, A becomes the humorous target of the utterance without that being detrimental to his public image, because they are a group of friends and $\mathrm{D}$ causes humour to create a positive effect on the conversation -strengthening their camaraderie ties- which is why politeness and group identity are reflected in this example of humour with a positive effect for the listener, that is A. The narrative strategy used in this conversation is irony with humour, in this case, we can see it by the appearance of laughter in conversation -the mark and the effect of humour, as GRIALE emphasizes (Ruiz Gurillo, 2012: $38)$.

In (5), the same interlocutors who appeared in the previous conversation talk about the topic of infidelity:

(5)

C: si no pasa ná $\downarrow$ porque tenemos todos cuernos $\uparrow$ no pasa nada

A: a mi no me ha puesto nadie los cuernos

B: se los ha puesto él

A: no he tenido ocasión de pon-de que me los pusieran aún

$B$ : se los has puesto tú a alguien ¿no?

A: tampocol/ se los han puestol/l yo no le he puesto a nadie los cuernos

$B$ : has colaborado activamente

A: por supuesto [(RISAS $)=]$

B: $\quad$ [(RISAS)]

$A:=$ pero yo lo hacía sin- $\sin$ conocimiento

B: $\quad \xi$ de causa/y de efecto (RISAS)

(Briz y grupo Val.Es.Co., 2002:65 [H.38.A.1:599-610])

C: But it's nuthin' $\downarrow$ because we all have horns [are cuckolds] $\uparrow$ nothing happens

A: nobody has cheated on me [made me a cuckold]

$B$ : he has cheated on him

A: I haven't had the chance to ch-to be cheated on yet

B: you have cheated on someone, haven't you?

A: I haven't either//he has been cheated on//I have never cheated on anyone

$B$ : you have collaborated actively

A: of course [(LAUGHTER $)=]$

B: [LAUGHTER]

$A:=$ but I did it - unknowingly

$B:=\quad$ [without knowledge] of causel and of effect [LAUGHTER] 
B tries to prove in (5) that A belongs to the group of "cornudos" [cuckolds] like the other group members, as he slept with a girl who was unfaithful to her boyfriend with him. The utterance is interpreted in an ironic and humorous way due to B's intervention has colaborado activamente [you have collaborated actively], which shows a diastratic variation because words belonging to the formal register in Spanish have been used in a colloquial conversation. The Principle of Manner has been violated as a result of B's words has colaborado activamente. A does not expect B's answer that is why it produces humour. Then we can observe that A participates in the same conversation and answers his interlocutor using a discourse marker that expresses agreement (por supuesto [of course]), with a literal meaning, and therefore A admits before his friends that he is a cornudo. Added to this is the intervention that he did it sin conocimiento (an adverbial phrase which means 'unknowingly') and B adds sin conocimiento de causa y efecto [without knowledge of cause and effect], which turns the colloquial phrase into a technical-looking expression that is typical of a more elaborate variety. So diastratic variation and its extension through the example produce a humorous utterance, where A's public image has been damaged by B but with a positive effect, because they are all friends and they strengthen their friendship with humour.

Moreover, the Principles of Informativity and Manner are violated, since the use of phraseology activates referents of the script opposition between poner los cuernos [cheating on someone] and que le pongan a alguien los cuernos [someone being cheated on] because the speaker draws a distinction between these two frameworks, not seeing himself as the agent of the action. So, there are two different perspectives: the existence of someone who cheats entails the existence of someone being cheated on ${ }^{20}$. A change of the logical mechanism is also interpreted by the listener, since the reasoning made by the speaker is correct, but the listener interprets it differently to produce irony and humour. The indicators used in this case -change of register and phraseology- act as a clue or jab line (-has colaborado activamente-), to trigger the punch line, (sin conocimiento de causa y efecto-). Moreover, the communicative situation takes place in a relaxed context with friends who are spending a day in the countryside. That is why the target of humour, although it is again A, does not aim at damaging his public image, but at showing group identity; in other words, it is humour with a positive effect for the friendship. The irony which appears in the utterance is used as a narrative strategy at the service of humour in conversation, as GRIALE's approach emphasizes (Ruiz Gurillo, 2012: 38).

(6) features the same interlocutors from the preceding examples who are now talking about an absent girl, a friend of D's:

(6)

B: ¿QUÉ has estao en su casa/ cabrón $\uparrow$ y te la has tirao ya?

D: no/ pero me lo dijo queee $\$$

A: $\quad \xi$ se la lleva todos los dias aaa casa hombre

D: sí/y en el coche $\uparrow /$ me coge la marcha $\uparrow$ y (RISAS) y me pone la primera/ tú pásame las [papaas]

C: $\quad$ [(RISAS)]

B: $\quad[(R I S A S)] / / /$ pues tú en seguida pones la marcha atrás ¿no Caty?

D: yo sí

(Briz and grupo Val.Es.Co., 2002:55 [H.38.A.1:195-204])

B: YOU SAY you've been at her house/ bastard $\uparrow$ and you've screwed her already?

D: no/but (she) told me thaaat

Open-access journal | www.europeanjournalofhumour.org 
A:

that he takes her home every day, man

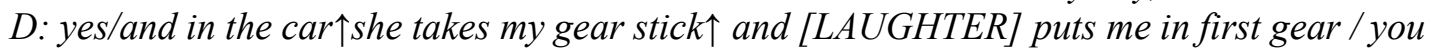
pass me the fries

C: [(LAUGHTER $)]$

B: $\quad[(L A U G H T E R)] / / /$ and you put the reverse gear right away, don't you, Caty?

D: I do

The participants in (6) expect D to confirm that he has made out with his girlfriend when giving her a lift in his car. However, as this was not the case, D answers his interlocutors with an ironic humorous utterance (si/ y en el coche/ me coge la marcha y me pone la primera [yes/ and in the car/ she takes my gear stick and puts me in first gear]) where he plays with the double sense of the verb coger (take), which acts as an indicator from GRIALE's approach because it has a double meaning in Spanish (sexual meaning and literal meaning); furthermore, he personalizes this play on words with the use of the pronoun my (me coge la marcha, me pone la primera) seeking to cause a stronger impact on his listener. We can therefore observe that an opposition of semantic scripts exists; on the one hand, we activate the semantic script llevar a su amiga en coche [give his girlfiend a lift in his car] and, on the other hand, that of tener sexo con ella [having sex with her]. It is the first jab line which appears in the fragment of the conversation and is giving the listener clues for its correct interpretation. This general script opposition favours incongruities in the situation where the participants find themselves; we should not forget that they are spending a day in the countryside. The target of humour is the absent girlfriend. In this case, irony and humour have a negative effect on a person, because her public image is damaged. D is suggesting that she is an easy girl. Nevertheless, this humorous utterance actually has positive effects on the conversational group because irony and humour are used as strategies to consolidate group identity and strengthen ties with the interlocutors by means of language. It is an example of continuing irony -ironic utterance continued by listener and speaker- where the interventions produce constant jab lines which the listener interprets humorously due to the breaking of expectations, as is shown to us by laughter.

We have the same interlocutors once again in (7). In this case, D suggests that his friends watch a movie in the evening, more precisely an action movie:

(7)

D:

video

[a ver $\downarrow$ esta] tarde se podía ver una película de

B: y mañana otra (RISAS)

A: nooo Caty/ no te envicies/ hay que descansar esta [tarde]

D:

deee acción

[no $\downarrow$ pero] un-película de video normal $\downarrow$ de esas

A: (RISAS)

$B$ : de acción (RISAS)

D: de acción/ hombre/// de Bruce Li [(RISAS)]

$B$ :

[Susi y Puti] se van de $\rightarrow$ (RISAS)

(Briz and grupo Val.Es.Co., 2002: 59 [H.38.A.1:355-364])

D: $\quad$ [well $\downarrow$ this] evening we could watch

a video movie

Open-access journal $\mid$ www.europeanjournalofhumour.org 
B: and tomorrow another one (LAUGHTER)

A: nooo Caty/ don't get hooked on that / we must rest this [evening]

$D$ :

[no $\downarrow$ I mean] a- normal video $\quad$ film $\downarrow$, one

of those aaaction ones

A: (LAUGHTER)

B: of action (LAUGHTER)

D: of action/ man/// of Bruce Li [(LAUGHTER $)]$

B: [Suzy and Whory] go on $\rightarrow($ LAUGHTER)

In (7) D wants to watch a film with his friends and makes a suggestion (well this evening we could watch a video movie), to which B answers provoking an irony with a positive effect, because he specifies the kind of film they can watch and he continues in his subsequent interventions. Action movie is a mark according to GRIALE's approach because of its double meaning. The Informativity Principle has been violated because a multiplication of referents has been created from the word movie and, as a result, the Principle of Manner has been violated as well. Thus, B echoes what has been previously said by his interlocutor D (-película de video_normal_de_esas_deee_acción [a normal video movie, one of those aaaction ones]) and gives a double meaning to the expression action movie; he plays with its metaphoric and polysemous use. In other words, there is a script opposition; on the one hand, we expect action movie and, on the other, we understand a pornographic movie.

Even though B's ironic intervention is answered by D, who defends his argument of watching an adventure -i.e. not erotic- movie, his words una película de video normal, de esas de acción serves as the jab line to express irony and it produces a humorous effect, as shown by the appearance of laughter. The target of humour is D but his public image is not damaged; in fact, irony is used as a narrative and communicative strategy which helps to strengthen the ties with his interlocutors, and is expressed through plays on words, as is clearly shown in the punch line, Susi y Puti se van de... [Suzy and Whory go on...]. This is consequently an example of humour and irony with a positive effect for the listener, because he produces humour to enhance their friendship.

In (8) the interlocutors are talking about a piece of news that appeared on television where it was explained that chocolate contained an antidepressant substance which can also be found in marijuana:

(8)

[E1]: El cho- el cho- si (--->)... el chocolate de comer [/simultáneo].

[H2]: ¡Huy!, pues a mi me gusta mucho, ¿eh?

[H3]: Si hablando de drogas, metes el chocolate (--->)... pues...

[E1]: Si (--->), la gente deprimida siempre en las películas toma bombones.

[H4]: Porque es má[(s)] barato [risas].

[E1]: Pero, bueno [silencio] y es eso, y lleva la misma sustancia que lleva la marihuana... y la gente por eso se queda más a gusto, por lo mismo, en vez de, de comerse una tableta de chocolate, te fumas un porro, y no engorda.

(Alcore, Covja, group 10)

[E1]: The cho- the cho- yes (--->)... the chocolate to eat [/simultaneous].

[H2]: Why! I like it very much actually, eh?

[H3]: Yes, talking about drugs, you put the chocolate in (--->)... so...

[E1]: Yes, (--->), depressed people in movies always eat chocolates. 
[H4]: Because it's mo[(re)]... cheap [laughter].

[E1]: But, well [silence] and it's that, and it has the same substance as marijuana... and that's why people feel more at ease; for the same reason, instead of eating a chocolate bar, you smoke a joint and it's not fattening.

The interlocutors in (8) produce a dialogue with a continuing irony. This happens because E1 uses the word chocolate and specifies that it is for eating (de comer). The script opposition consequently appears the same as in the preceding cases, because the listener interprets chocolate as food on the one hand but, on the other hand, he understands chocolate as drug (its other slang meaning in Spanish). In other words, faced with an incongruity, the interlocutor resolves the situation with the most suitable interpretation in this context. The Informativity Principle has consequently been violated because a multiplication of referents has been created from the polysemy in the word chocolate (chocolate as cocoa and chocolate as marijuana) and, as a result, the Principle of Manner has been violated as well, because something has been said in a marked way (it has been specified that the chocolate was for eating). In addition to that, $\mathrm{H} 4$ thinks it appropriate to make the comment porque es más barato [because it is cheaper], an intervention which is used by the other interlocutors as a jab line to show a humour mark, in which the target is the gente deprimida [depressed people], i.e. third persons who are absent in the conversation. Irony is thus used as a communicative strategy to produce humour with a positive effect for a situation, because they are talking about depressed people, not about themselves. So the participants in this communicative act have reinforced their ties in the conversational group and that additionally causes a continuing humorous effect, which creates an atmosphere of understanding between them, as is reflected by the appearance of laughter.

The interlocutors in (9) are the same ones who appeared in example (1). In this case, they have dropped the bottle stopper and do not clean it before putting it in its place again:

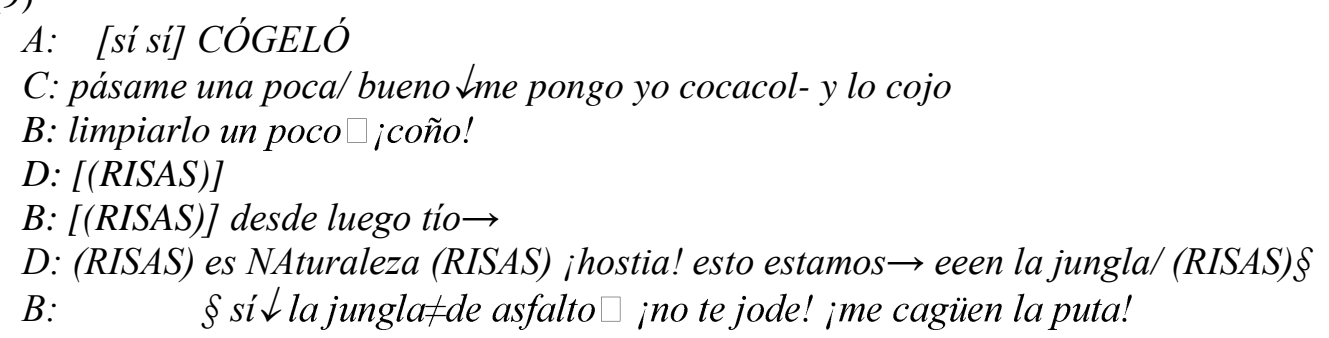

(Briz and grupo Val.Es.Co., 2002: 51 [H.38.A.1:41-49])

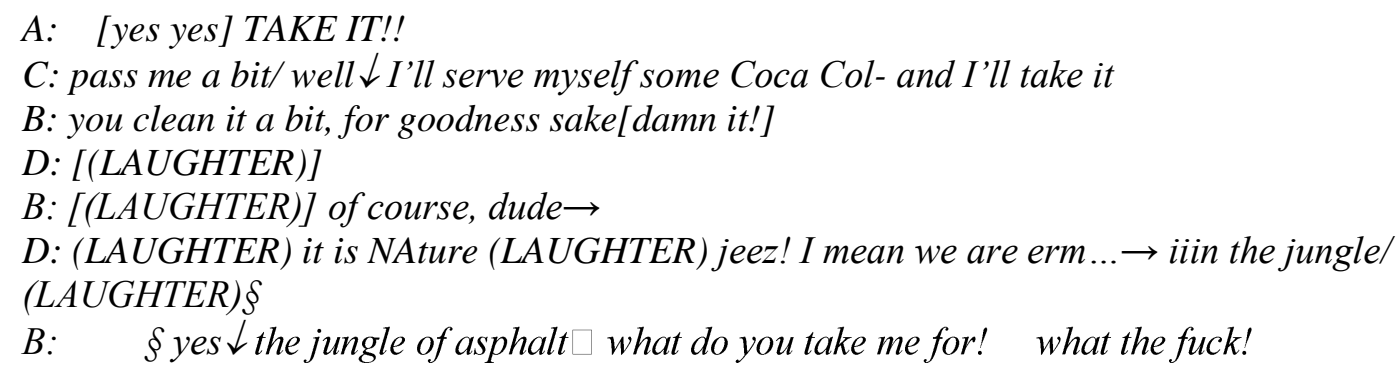

In (9) D has taken the Coca-Cola bottle stopper which had fallen on the ground, but he has not cleaned it before placing it again in the bottle, as shown by B's use of the subjective routine formula desde luego tio [Oh my god, dude!], which generates a script opposition that 
produces humour, as everybody expects D to clean the stopper and he does not. The logical mechanism is based on a correct reasoning, as he was supposed to have cleaned it. The narrative strategy used is irony. The Principle of Manner has been violated because something has been said in a marked way (it has been specified that they are in the jungle). Thus, D finds himself in a communicative situation with friends in which it is appropriate not to clean the stopper, as shown by its subsequent ironic intervention es NAturaleza (RISAS) ;hostia! esto estamos $\rightarrow$ eeen la jungla [it is Nature (LAUGHTER) jeez! erm... we are $\rightarrow$ iiin the jungle].

In this way, D becomes the target of humour without that having been his intention at the beginning of his intervention -as we can see with laughter and B's intervention- and is then forced to protect his damaged face, as a result of his acts because he does not clean the stopper. In this case, we have humour with a positive effect in the friendship group to save D's negative public face, because it is an example of self-humour intended to protect his public image that had already been unconsciously damaged by himself.

\section{Conclusions}

After having carried out the analysis of colloquial conversation examples, I can conclude that:

-Firstly, these utterances contain non-prototypical irony and humour; in other words, the speakers do not say the opposite of what they say, which means that they say something different that makes the utterances ironic and, therefore, the aim is to strengthen ties with the interlocutor, even if that implies attacking the public image of others, as in (6).

-Secondly, the examples confirm that irony and humour are mostly used to show solidarity, which I call positive effect, an idea that authors such as Attardo (2001b: 174), Kotthoff (2007: 264), Holmes and Marra (2002: 1684) and Hay (2000: 716), among others, often link exclusively to humour. I have demonstrated in (4), (5), (7), (8) and (9) that irony and humour coexist in conversational utterances in Spanish and they may cause a positive effect, thus following the scheme proposed in Alvarado (2009). In other words, they are conversational strategies at the service of interlocutors and they can consequently be used to include or exclude someone from the conversational group. This means that the traditional belief according to which humour was exclusively linked to negative irony is no longer valid in conversation. To summarize, Figure 2 illustrates the breakdown of humorous instances that appeared in our conversational corpus in terms of percentages:

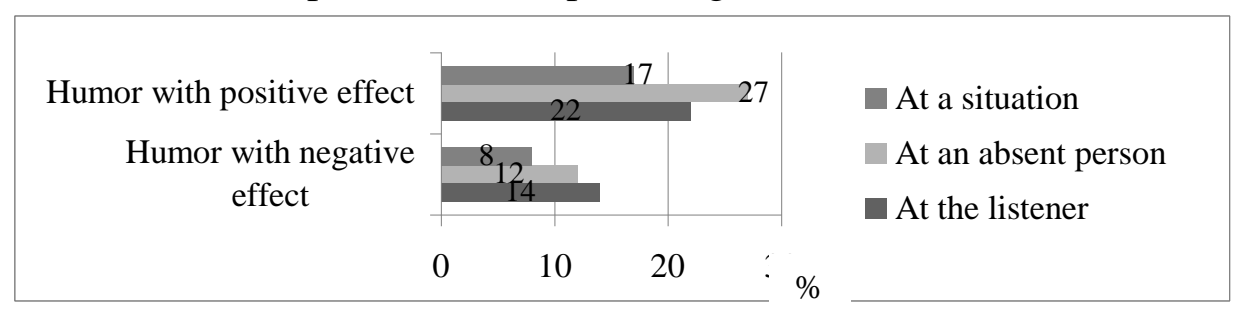

Figure 2. Humour in conversational examples

-Ironic-humorous utterances with a positive effect are predominant in Spanish (see Figure $2,66 \%$ ). The reason is probably that humour and irony are never used to attack the public image of any participants; instead, they help to strengthen ties between them, as we have seen in (5), for example. Ironic-humorous utterances with a negative effect are less frequent in Spanish (see 
Figure 2, 34\%), because the speakers do not want to damage their public face, as we have seen in (9).

-It seems clear from the examples analyzed that the speaker does not have a humorous intention at the beginning of the utterance. What happens is that polysemy and plays on words which are used not only as indicators of humour and irony but also as jab lines - turn the intervention into a humorous one, that is, humour arises due to the opposition of semantic scripts and the violation and inversion of the Principles of Informativity and Manner, which favour continuing irony between speaker and listener.

-In short, I have shown that GRIALE's theoretical model -based on indicators, marks and inversion of principles, and Attardo's GTVH model -based on knowledge resources, complement each other to explain ironic-humorous utterances emerging from the violation and inversion of conversational principles, which are followed by a series of generalizable inferences which the listener has to interpret in an ironic way. Therefore, humour with a positive effect is one of the values which the ironic utterance can convey in conversation after breaking the listener's expectations.

\section{Notes}

\footnotetext{
${ }^{1}$ This paper has been possible thanks to the Project FFI2012-30941: “Innovaciones lingüisticas del humor: géneros textuales, identidad y enseñanza del español" [Linguistic innovations of humour: textual genres, identity and Spanish learning]. A shorter version of this article has been published in Procedia - Social and Behavioral Sciences (Alvarado, 2013: 594-603).

${ }^{2}$ This assertion is based on the premise that conversation is not a humorous genre per-se (See Ruiz Gurillo 2012, section 4; Kotthoff 2000, among others).

3 There are other researchers that support the claim that humour is positive and polite, see Holmes (2000), Antonopoulou and Sifianou (2003), Schnurr et al. (2005), Carranza Márquez (2010), amongst others.

${ }^{4}$ There are three main groups of theories (Raskin, 1985: 31-36) which deal with verbal humour: the Incongruity Theories; the Aggression Theories, and the Release Theories. Attardo's General Theory of Verbal Humor (GTHV) is located within the group of Incongruity Theories, as he himself has made clear (Attardo, 2001a: 22).

${ }^{5}$ To obtain more information on this topic, see the issue of Journal of Pragmatics, 35 (2003), dedicated to humour.

${ }^{6}$ For the details of the method developed by GRIALE, see Ruiz Gurillo and Padilla (2009).

${ }^{7}$ See also Attardo (2001), Ruiz Gurillo et al. (2004), Ruiz Gurillo and Padilla (2009) and Alvarado (2005).

${ }^{8}$ Inversion is a technical term in the model (see Rodríguez Rosique, 2009: 120).

${ }^{9}$ Levinson outlines a neo-Gricean theory according to which the inferential reconstruction of the speaker's intentions is based on what is salient for the interlocutors. Levinson agrees with Grice's view that the meaning of an utterance is a composite of what is said and what is conventionally and conversationally implicated. This leads him to a reformulation of the maxims as heuristics, for example Heuristic 2: "What is expressed simply is stereotypically exemplified." (Levinson 2000: 37). He sees this as a reformulation of Grice's second Maxim of Quantity: "Do not make your contribution more informative than is required." Levinson's Heuristic 3: "What's said in an abnormal way isn't normal" can be related to Grice's Maxim of Manner.

${ }^{10}$ For specifics on this idea, see Ruiz Gurillo and Padilla (2009).

${ }^{11}$ Kotthoff (1996) arrives at the gradations from polite to impolite humorous speech activities.

${ }^{12}$ I understand politeness as a conversational strategy to avoid conflicts and maintain good relationships between interlocutors (Alvarado, 2005: 36).

${ }^{13}$ See also Matthews et al. (2006) for other studies relating politeness and humour.

${ }^{14}$ The direct link between politeness and humour has been studied by Holmes (2000), and Holmes and Marra (2002).

15 The idea that humour is a conversational strategy has been analyzed by authors such as Archakis \& Tsakona (2005), who state that humour builds the identity of speakers.
} 
${ }^{16}$ The transcription system developed by Val.Es.Co. Group (Briz \& Grupo Val.Es.Co., 2002: 29-31), see http://www.valesco.es/sistema.pdf. We will see the original examples in Spanish, and their translations into English.

${ }^{17}$ Laughing.

${ }^{18} \mathrm{D}$ ironically reproduces what he supposes that A could have stated.

${ }^{19}$ For the connection between laughter and humour, see Attardo (2008: 120), Archakis \& Tsakona (2005: 44), Hay (2000: 711) or Kotthoff (2000: 64), amongst others.

${ }^{20}$ In linguistic semantics these are termed "converse terms".

\section{References}

Alba, J. L. (1995). 'Verbal irony and the maxims of Grice's Cooperative Principle'.

Revista alicantina de estudios ingleses 8, pp. 25-30.

Alba J. L. (2001). The Functions and Strategies of Ironic Discourse: An Analysis. Madrid: Servicio de Publicaciones.

Alvarado, M. B. (2005). 'La ironía y la cortesía: una aproximación desde sus efectos'. ELUA 19, pp. 33-47.

Alvarado, M. B. (2006). 'Las marcas de la ironía'. Interlingüistica 16, pp.1-11. URL: www.ajl.uma.es

Alvarado, M. B. (2009). 'Ironía y cortesía', in Ruiz Gurillo, L. \& Padilla Garcia, X. (eds.), Dime cómo ironizas y te diré quién eres: una aproximación pragmática a la ironía, Frankfurt: Peter Lang, pp. 333-345.

Alvarado, M. B. (2010). Las fórmulas rutinarias del español: teoría y aplicaciones. Frankfurt: Peter Lang.

Alvarado, M. B. (2012). 'El humor en los enunciados irónicos conversacionales'. Oralia, pp. 63-76.

Alvarado, M. B. (2013). 'An approach to verbal humor in interaction'. Procedia: Social and Behavioral Sciences 95, pp. 594-603.

Antonopoulou E. \& Sifianou, M. (2003). 'Conversational dynamics of humor: The telephone game in Greek'. Journal of Pragmatics 35, pp. 741-769.

Archakis, A. \& Tsakona, V. (2005). 'Analyzing conversational data in GTVH terms: A new approach to the issue of identity construction via humor'. Humor. International Journal of Humor Research 18, pp. 41-68.

Attardo, S. (2000). 'Irony markers and functions: Towards a goal-oriented theory of irony and its processing'. Rask 12, pp. 3-20.

Attardo, S. (2001a). Humorous Texts: A Semantic and Pragmatic Analysis. Berlin: Mouton De Gruyter.

Attardo, S. (2001b). 'Humor and irony in interaction: from mode adoption to failure of detection', in Anolli, L., Ciceri, R. \& Riva, G. (eds.), Say not to Say: New Perspectives on Miscommunication, Amsterdam: IOS Press, pp. 166-186.

Attardo, S. (2003). 'Multimodal markers of irony and sarcasm'. Humor: International Journal of Humor Research 16 (2), pp. 243-260.

Attardo, S. (2008). 'A primer for the linguistics of humor', in Raskin, V. (ed.), The Primer of Humor Research, Berlin: Mouton de Gruyter, pp. 101-155.

Attardo, S. \& Raskin, V. (1991). 'Script theory revis(it)ed: Joke similarity and joke representation model'. Humor: International Journal of Humor Research 4, pp. 293-347. 
Azorín Fernández, D. (Coord.) (2002). ALCORE. Alicante Corpus del Español. CD.

Bravo, D. (ed.) (2003). Actas del Primer coloquio del programa EDICE: La perspectiva no etnocentrista de la cortesía: identidad sociocultural de las comunidades hispanohablantes. Stockholm: University of Stockholm.

Bravo, D. \& Briz, A. (eds.) (2004). Pragmática sociocultural: estudios sobre el discurso de cortesía en español. Barcelona: Ariel.

Briz, A. \& Grupo Val.Es.Co. (2002). Corpus de conversaciones coloquiales. Madrid: Arco Libros.

Brown, P. \& Levinson, S. (1978, 1987). Politeness: Some Universals in Language Usage. New York: Cambridge University Press.

Carranza Márquez, A. (2010). 'The faces of humor: Humor as catalyst of face in the context of the British and the Spanish parliament'. Humor: International Journal of Humor Research 23, pp. 467-504.

Clift, R. (1999). 'Irony in conversation'. Language in Society 28, pp. 523-553.

Díaz Pérez, F. J. (2003). La cortesía verbal en inglés y en español. Actos de habla y pragmática intercultural. Jaén: Universidad de Jaén.

Ducrot, O. (1986). 'Esbozo de una teoría polifónica de la enunciación', in El decir y lo dicho. Polifonía de la enunciación. Barcelona: Paidós, pp. 175-238.

Escandell Vidal, M. V. (1995). 'Cortesía, fórmulas convencionales y estrategias indirectas'. Revista Española de Lingüística 25 (1), pp. 21-66.

Escandell Vidal, M. V. (1996). Introducción a la Pragmática. Barcelona: Ariel.

Fernández García, F. (2001). 'Ironía y (des)cortesía', Oralia 4, pp. 103-127.

Garmendia, J. (2010). 'Irony is critical'. Pragmatics and Cognition 18 (2), pp. 397-421.

Gibbs, R. W. Jr. (2000). 'Irony in talk among friends'. Metaphor and Symbol 15 (1-2), pp. 528.

Goffman, E. (1981). Forms of Talk. Oxford: Blackwell.

Grice, H. P. (1975, 1991). 'Lógica y conversación', in Valdés, L. (ed.), La búsqueda del significado. Murcia: Tecnos, pp. 511-530.

Gruner, Ch. (1978). Understanding Laughter: The Workings of Wit \& Humor. Chicago: Nelson.

Gruner, Ch. (2000). The Game of Humor. A Comprehensive Theory of Why We Laugh. New Jersey: Library of Congress.

Haverkate, H. (1985). 'La ironía verbal: análisis pragmalingüístico', Revista Española de Lingüística 15 (2), pp. 343-391.

Haverkate, H. (1990). 'A speech act analysis of irony'. Journal of Pragmatics 14, pp. 77110.

Haverkate, H. (1994). La cortesía verbal. Estudio pragmalingüístico. Madrid: Gredos.

Haverkate, H. (2003). 'El análisis de la cortesía comunicativa: categorización pragmálingüística de la cultura española', in Bravo, D. (ed.), Actas del Primer coloquio del programa EDICE: La perspectiva no etnocentrista de la cortesía: identidad sociocultural de las comunidades hispanohablantes. Stockholm: University of Stockholm, pp. 60-70.

Hay, J. (2000). 'Functions of humor in the conversation of men and women'. Journal of Pragmatics 32, pp. 709-742. 
Hidalgo, R. \& Iglesias, S. (2009). 'Humor e Ironía: una relación compleja', in Ruiz Gurillo, L. \& Padilla Garcia, X. (eds.), Dime cómo ironizas y te diré quién eres: una aproximación pragmática a la ironía, Frankfurt: Peter Lang, pp. 423-455.

Holmes, J. (2000). 'Politeness, power and provocation: How humor functions in the workplace'. Discourse Studies 2, pp. 159-185.

Holmes, J. (2006). 'Sharing a laugh: Pragmatic aspects of humor and gender in the workplace'. Journal of Pragmatics 38, pp. 26-50.

Holmes, J. \& Marra, M. (2002). 'Having a laugh at work: how humor contributes to workplace culture'. Journal of Pragmatics 34, pp. 1683-1710.

Holmes J. et al. (2005). 'Politeness, humor and gender in the workplace: negotiating norms and identifying contestation'. Journal of Politeness Research 1, pp. 121-149.

Horn, Laurence H. ([1984] 1998). 'Towards a new taxonomy for pragmatic inference: Qbased and R-based implicature', in Kasher, A. (ed.), Pragmatics IV, London: Routledge, pp. 383-418.

Kotthoff, H. (1996). 'Impoliteness and conversational joking: On relational politics'. Folia Linguistica 30 (3-4), pp. 299-327.

Kotthoff, H. (2000). 'Gender and joking: on the complexities of women's image politics in humorous narratives'. Journal of Pragmatics 32, pp. 55-80.

Kotthoff, H. (2003). 'Responding to irony in different contexts: on cognition in conversation'. Journal of Pragmatics 35, pp. 1387-1411.

Kotthoff, H. (2006). 'Gender and humor: The state of the art'. Journal of Pragmatics 38, pp. 4-25.

Kotthoff, H. (2007). 'Oral genres of humor: on the dialectic of genre knowledge and creative authoring'. Pragmatics 17, pp. 263-296.

Lakoff, R. (1973). 'The logic of politeness or minding your p's and q's', Papers from the Ninth Regional Meeting of the Chicago Linguistic Society. Chicago: Chicago Linguistic Society, pp. 292-305.

Leech, G.H. (1983). Principles of Pragmatics. London: Longman.

Levinson, S. (2000). Presumptive Meanings. Cambridge: MIT Press.

Matsumoto, Y. (1988). 'Reexamination of the universality of face: Politeness phenomena in Japanese'. Journal of Pragmatics 12, pp. 403-426.

Matthews, J., Hancock, J. \& Dunham, P. (2006). 'The roles of politeness and humor in the asymmetry of affect in verbal irony'. Discourse Processes 41 (1), pp. 3-24.

Muecke, D. C. (1978). 'Irony markers'. Poetics 7, pp. 363-375.

Norrick, N. (1993). Conversational Joking: Humor in Everyday Talk. Bloomington: Indiana University Press.

Norrick, N. (2003). 'Issues in conversational joking'. Journal of Pragmatics 35, pp. 13331359.

Norrick, N., D. Ch. (2009). Humor in Interaction. Amsterdam: John Benjamins.

Priego Valverde, B. (2006). 'How funny it is when everybody gets going! A case of coconstruction of humor in conversation'. Círculo de Lingüistica aplicada a la comunicación 27, pp. 72-100.

Raskin, V. (1985). Semantic Mechanisms of Humor. Dordrecht: D. Reidel.

Ritchie, D. (2005). 'Frame-shifting in humor and irony'. Metaphor and Symbol 20, pp. 275294. 
Rodríguez Rosique, S. (2009). 'Una propuesta neogriceana', in Ruiz Gurillo, L. \& Padilla Garcia, X. (eds.), Dime cómo ironizas y te diré quién eres: una aproximación pragmática a la ironía, Frankfurt: Peter Lang, pp. 109-133.

Rogerson-Revell, P. (2007). 'Humor in business: a double-edged sword. A study of humor and style shifting in intercultural business meetings'. Journal of Pragmatics 39, pp. 4-28.

Ruiz Gurillo, L. (2006). Hechos pragmáticos del español. Alicante: Servicio de Publicaciones de la Universidad de Alicante.

Ruiz Gurillo, L. (2009). ‘CCómo se gestiona la ironía en la conversación?’. Rilce 25 (2), pp. 363-377.

Ruiz Gurillo, L. (2010). Para una aproximación neogriceana a la ironía y al humor en español'. RFE, pp. 95-124.

Ruiz Gurillo, L. (2012) . La lingüística del humor en español. Madrid: Arco Libros.

Ruiz Gurillo, L. \& Padilla Garcia, X. (eds.) (2009). Dime cómo ironizas y te diré quién eres: una aproximación pragmática a la ironía. Frankfurt: Peter Lang.

Ruiz Gurillo, L. \& Alvarado Ortega, M. B. (eds.) (2013). Irony and Humor. From Pragmatics to Discourse. Amsterdam/Philadelphia: John Benjamins.

Schnurr, S.; Marra, M. \& Holmes, J. (2005). 'Impoliteness as a means of contesting power relations in the workplace', in Bousfield, D. \& Locher, M. A. (eds.), Impoliteness in Language: Studies on its Interplay with Power in Theory and Practice. Berlin: Mouton de Gruyter, pp. 211-231.

Schoentjes, P. (2003). La poética de la ironía. Madrid: Cátedra.

Suls, Jerry M. (1972). 'A two-stage model for the appreciation of jokes and cartoons: An information-processing analysis', in Goldstein, J. H. \& McGhee, P. E. (eds.), The Psychology of Humor. Theoretical Perspectives and Empirical Issues, New York: Academic Press, pp. 81-100.

Torres Sánchez, M. A. (1999). Aproximación pragmática a la ironía verbal. Cádiz: Servicio de Publicaciones de la Universidad de Cádiz.

Wilson, D. \& Sperber, D. (2004). 'La teoría de la relevancia', Revista de Investigación Lingüística 7, pp. 233-282.

Yus, F. (1996). 'La Teoría de la Relevancia y la estrategia humorística de la incongruenciaresolución'. Pragmalingüística 3-4, pp. 497-508. 